\title{
ICEBAMO 98
}

\section{$4^{\text {th }}$ INTERNATIONAL CONFERENCE ON ENVIRONMENTAL AND BIOLOGICAL ASPECTS OF MAIN GROUP ORGANOMETALS}

The ICEBAMO meetings aim to facilitate interdisciplinary discussion on environmental and biological aspects of main-group organometals. Previous meetings in Padua (1986 and 1991) and Bordeaux (1994) have brought together researchers from the fields of toxicology, environmental sciences, analytical chemistry, biochemistry, and synthetic organometallic chemistry.

The fourth meeting in the ICEBAMO series will take place in Denmark from 28 June to 2 July 1998 at the Gammel Avernæes Conference Centre on the beautiful island of Funen. The conference will provide a forum for discussion of the following aspects of organometallic compounds:

- Origin and pathways in the environment

- Fate in organisms including accumulation and toxicological effects

- Biological and biochemical studies on transformation/detoxification processes

- Analytical chemistry including analysis of chemical species

- Main group metal-based drugs

The meeting will consist of oral presentations and posters with a strong emphasis on scientific discussion. Accordingly, ample time for questions and discussion will be made available both during the formal sessions and afterwards while relaxing in the picturesque surroundings of Gammel Avernæs.

A detailed announcement and call for abstracts will be released in July 1997 . Meanwhile, further information may be obtained from:

Kevin A. Francesconi

Institute of Biology

Odense University

DK-5230 Odense M

Denmark

Fax: (45) 65930457

E-mail: kaf@biology.ou.dk 



\title{
4TH FRANCE GREECE ITALY PORTUGAL SPAIN (FGIPS) MEETING IN INORGANIC CHEMISTRY
}

\author{
October 14 - 18, 1997 \\ Corfu, Greece
}

\begin{abstract}
HONORARY COMMITTEE
Marc JULIA, Société Francaise de Chimie

Nikos KATSAROS, Association of Greek Chemists

George PNEUMATIKAKIS, Association of Greek Chemists

Ivano BERTINI, Italian Chemical Society

Romano CIPOLINI, National Research Council of Italy

Romao DIAS, A., National Research Council of Portugal

Formosinho SANCHES, A., Portuguese Chemical Society

Juan RODRIGUEZ-RENUNCIO, Spanish Chemical Society

Jose R. MASAGUER, Spanish Chemical Society
\end{abstract}

\author{
INTERNATIONAL SCIENTIFIC COMMITTEE \\ Gilbert G. A. BALAVOINE, France \\ Jacques LIVAGE, France \\ Roger GUILARD, France \\ Nikos KATSAROS, Greece \\ Claudio BIANCHINI, Firenze, Italy \\ Antonio SGAMELLOTTI, Perugia, Italy \\ Jose MOURA, Portugal \\ Jose M. GONZALEZ-CALBET, Spain \\ Nikos HADJILIADIS, Greece \\ Theofilos THEOPHANIDES, Greece \\ Giovani NATILE, Bari, Italy \\ Maria Jose CALHODRA, Portugal \\ Manuel ALMEIDA, Portugal \\ Virtudes MORENO, Spain
}

Pablo ESPINET, Spain

\section{LOCAL ORGANIZING COMMITTEE}

Nikos KATSAROS, NCSR "Demokritos" (Chairman)

George PNEUMATIKAKIS, Univ. of Athens Nick HADJILIADIS, Univ. of loannina

Nick KALOGERAKOS, Univ. of Athens

Costas MERTIS, Univ. of Athens

Athanassios KOUTSOLELOS, Univ. of Crete Spyros PERLEPES, Univ. of Patras

Costas METHENITIS, Univ. of Athens

Dimitris KESSISSOGLOU, Univ. of Salonika

\section{CONFERENCE SECRETARIAT}

Dr. Aglaia KOUTSODIMOU

NCSR "Demokritos", Inst. Physical Chemistry

GR-153 10 Ag. Paraskevi Attikis, GREECE

Tel: $+3016513111-9$ ext 131, Fax: +3016511766

e-mail: koutsod@cyclades.nrcps.ariadne-t.gr

\section{SCIENTIFIC PROGRAM}

The fourth French, Greek, Italian, Portuguese, Spanish meeting (4th FGIPS) will be held in Corfu, Greece, from October 14 to October 18, 1997.

The symposium will resemble the previous GIPS meetings (Gandia 1990, Algarve 1992 and Senigallia 1995) which were attended by two to four hundred scientists with expertise in:

Coordination and Bioinorganic Chemistry

Organometallic Chemistry and Catalysis

Solid State Chemistry and Materials 
The program will emphasize cross disciplinary relations and promote interactions among participants of the five different countries.

There will be plenary lectures, session lectures and minisymposia on the following topics:

1. Reaction Mechanisms

2. Metals in Medicine

3. Models for Metalloenzymes

4. Asymmetric Synthesis

5. Homogel)eous Catalysis

6. Stmctule and Reactivity of Organometallic Compounds

7. Magnetic, Electronic and Optical Properties of Materials

8. Surface Chemistry and Catalysis

9. Synthesis and Structural Characterization of Materials

10. Environn1ental Inorganic Chemistry

11 .Inorganic Chemistry and Nutrition

12. Theoretical Aspects in Inorganic Chemistry

\section{Submission of Abstracts for contributed papers}

Papers are welcome on research that is related to the cited topics.

Abstract forms and instructions will be given in the Second circular.

Registration fees will be 120USD for active participants and 80USD for accompanying persons. To encourage attendance by young scientists, registration fees will be reduced to 8OUSD for graduate students who present oral papers or posters.

Registration forms and instructions will also be given in the second circular.

Approximate fare for half board pension will be:

Hotel CHANDRIS ****

Half board, single room: 75USD

Half board, double room: 53USD per person

Conference will take place at the hotel CHANDRIS

\section{Venue and Accommodation}

The meeting will be held in Corfu (Greece) a beautiful island connected by sea and air to Athens. In October the average temperature is about $20^{\circ} \mathrm{C}$. Accommodation will be available in convenient and comfortable hotels located at the seashore and at walking distance from lecture halls.

Information on hotel accommodations, air and sea connections will be given in the second circular. 